\title{
ACUTE RESPIRATORY DISTRESS SYNDROME AS A COMPLICATION OF VIRAL PNEUMONIA - CASE REPORT
}

\author{
Bećir Nevenka, ${ }^{1}$ Milačić Nena, ${ }^{2}$ Kovijanić Zlata, ${ }^{2}$ Bogojević Milan, ${ }^{2}$ Milačić Bojan ${ }^{3}$ \\ ${ }^{1}$ Department of Internal Medicine, General Hospital Kotor, Montenegro \\ ${ }^{2}$ Department of Internal Medicine, Clinical Center of Montenegro, Podgorica Montenegro \\ ${ }^{3}$ Department of Thoracic Surgery, Clinical Center of Montenegro, Podgorica, Montenegro
}

Primljen / Received 07. 12. 2017. god.

Abstract: ARDS is a life-threatening condition that requires monitoring in intensive care units. There is no specific treatment. We present a 49 year-old female patient with ARDS and its complications, ventilation assisted pneumonia (VAP) andbilateral pneumothorax.Good knowledge of the process can help to choose the appropriate treatment and to prevent or to recognize possible complications. Adequate oxygen therapy takes important place in treatment of these patients.

Key words: ARDS, intensive care unit, ventilation assisted pneumonia, bilateral pneumothorax, oxygen therapy

\section{INTRODUCTION}

The definition of ARDS was given in 2011 by The European Society of Intensive Care Medicine, supported by The American Thoracic Society and the Society of Critical Care Medicine and it is known as the Berlin Definition. According to it, ARDS is defined by time (one week from a clinical insult or a worsening of the chronic condition); radiographic changes (bilateral shadows, not fully explained by effusion, consolidation, atelectases); presence of lung edema in the absence of left heart failure and $\mathrm{PaO} 2 / \mathrm{FIO} 2$ ratio with a minumum of $5 \mathrm{~cm}^{2} \mathrm{H} 20$ continuous positive airway pressure (CPAP). By definition, 3 ARDS categories have been identified. Subtypes are based on the degree of hypoxemia: mild ( $\mathrm{PaO} 2 /$ FIO2 $\leq 300 \mathrm{~mm} \mathrm{Hg}$ ), moderate $(\mathrm{PaO} 2 / \mathrm{FIO} 2 \leq 200 \mathrm{~mm} \mathrm{Hg})$, and severe $(\mathrm{PaO} 2 /$ FIO2 $\leq 100 \mathrm{~mm} \mathrm{Hg})(1,2)$.

ARDS implies diffuse alveolar injury (DAD) and injury to the capillary endothelium in the lungs. Injuries of the capillary endothelium and alveolar epithelium lead to impaired fluid transport through alveoli and fluid
Prihvaćen/Accepted 20. 01. 2018. gos.

accumulation rich in proteins within the alveoli, eventually leading to diffuse alveolar injury, with the release of proinflammatory cytokines, such as Tumor Necrosis Factor (TNF), IL-1 and IL-6 (3). Neutrophils are activated, releasing toxic mediators, proteases and free radicals (4). Abnormalities of transcription factors, including NF-cap B needed for gene transcription for many pro inflammatory mediators, are present in ARDS (5). Endothelin-1, angiotensin-2 and phospholipase A-2 also significantly increase vascular permeability.

The loss of epithelial integrity in ARDS has many consequences. First, under normal conditions, the epithelial barrier is much less permeable than the endothelial. Thus, epithelial injury contributes more to alveolar leakage. Secondly, the loss of epithelial integrity and injuries of epithelial cells type II impairs normal fluid and ion exchange, leading to edema within the alveolar space. Thirdly, pneumocyte type II injury reduces the production of surfactants leading to known abnormalities. Fourth, loss of the epithelial barrier can lead to septic shock in patients with bacterial pneumonia. Finally, if the injury of the alveolar epithelium is serious, the inability to regenerate ultimately leads to fibrosis. The fibrosis process was stimulated by interleukin (IL) -1. Progression to fibrosis can be predicted by the increased values of procollagen peptide III (PCP-III) in the sample obtained by BAL. The diseases most commonly associated with ARDS can be both lungs and systemic (Table 1). Mycobacteria pneumoniae, although associated with unilateral pneumonia, can also lead to changes that correspond to acute respiratory distress syndrome $(6,7)$.

The main symptoms include breathing difficulties (dyspnoea), rapid breathing (tachypnoea), and extremely deep breathing (hyperventilation) and reduced oxygen levels in the circulation (hypoxemia). Usually 
Table 1. ARDS related diseases and conditions

\begin{tabular}{|l|l|}
\hline Pulmonary diseases or conditions & Systematic diseases or conditions \\
\hline Pneumonia & Sepsis \\
\hline Aspiration of gastric contents & $\begin{array}{l}\text { Difficult trauma:Multiple fractures } \\
\text { Head injuries } \\
\text { Burns }\end{array}$ \\
\hline Lung Contusion & Multiple Transfusion \\
\hline Drowning & Overdose of narcotics \\
\hline Inhalation lung injury & Pancreatitis \\
\hline & Post Cardiopulmonary bypass \\
\hline
\end{tabular}

it occurs 24 to 48 hours after the onset of the underlying disease or worsening of the existing one. One of the most significant characteristics of ARDS is that there is hypoxemia refractor to oxygen therapy, and therefore patients are subjected to mechanical ventilation. One of the most common complications of mechanical ventilation is bacterial pneumonia, which is usually caused by gram negative bacteria (P. aeruginosa, Acinetobacter baumannii, and Stenotrophomonas maltophilia) $(40 \%)$, then Enterobacteriaceae (29\%) and MRSA $(21 \%)$ In the laboratory tests we often find an increased number of white blood cells, which speaks for pneumonia or sepsis. Acido base status may show reduced $\mathrm{H}<7$.4. On the RTG image of the lung we find the presence of edema. CT may sometimes be needed, but usually a RTG record is sufficient. Ultrasound of the heart helps to exclude heart problems. Monitoring with arterial pulmonary catheter excludes the existence of pulmonary hypertension. Bronchoscopy can be considered if there is a need for evaluation of lung condition.

\section{CASE REPORT}

A 49 years old female was admitted to the Clinical Hospital Center of Montenegro pulmology department through Emergency Center due to choking, dry cough, weakness and fatigue, elevated body temperature. The illness started seven days before with mentioned problems that intensified by time, after which she was admitted to the General Hospital Berane. During treatment in the Berane General Hospital, a PCR test for influenza $\mathrm{A}$ and $\mathrm{B}$ was performed. The findings were sent for analysis to the Public Health Institute. Lung RTG was performed and bilateral pneumonia was noticed. In past medical history she reported diabetes mellitus type 2 with metformin therapy.

On admission to the Emergency Center, she was conscious, oriented, mobile.Discrete dyspnoea atrest was present, tachycardia, temperature $38.3^{\circ} \mathrm{C}$, cyanotic lips, dry plated tongue with herpetic changes in the labial region. The conclusion was that she leaves the- impression of a medium sick patient. A skin was of a reduced turgor, with no signs of hemorrhagic syndrome. Auscultatory fine crackels were heard at basal parts of lung. In the obtained laboratory tests, the increase in inflammatory parameters with elevated values of $\mathrm{D}$ dimer and liver function parameters were verified (WBC 14.3, Hgb 124, PLT 331, CRP 147.6, AST 142, ALT 240, GGT 227, LDH 751, CK 68, K 3.8, Na 137, $\mathrm{D}$ dimer $>36.436$ ). The performed ABB showed a global respiratory insufficiency, metabolic compensated (p H 7.43, p CO2 6.1, p O2 5.1, HCO3 28.4, hco3 STD 26.1, BE 5.3, with O2 84\%). On the performed RTG recording of the lungs in the $\mathrm{UC}$, the bilateral shading of the lower and middle lung fields was described. CT of lung arteries excluded the presence of lung thromboembolism and described the consolidation of the lung parenchyma starting from lung apexand going through the middle and dorsobasal segments with the manifestation of typical signs of pulmonary edema. Hospital treatment was indicated

Soon after the admission to the pulmonary department, the patient's condition worsened. Central cyanosis occurred and repeated ABB showed: p H 7.51, p $\mathrm{CO} 2$ 5.3, p O2 3.8, $\mathrm{HCO} 3$ 30.4, $\mathrm{BE}$ 8.2, $\mathrm{SaO} 2$ 63.5,

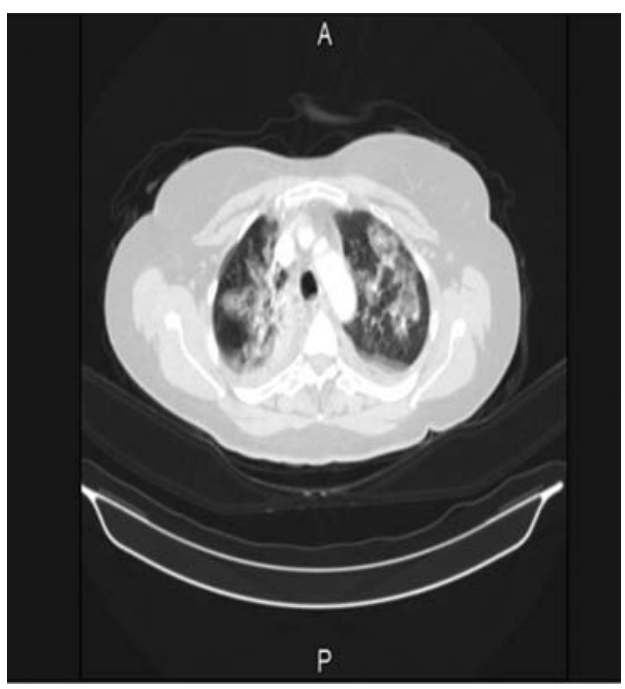

Figure 1-CT of patient's lungs 


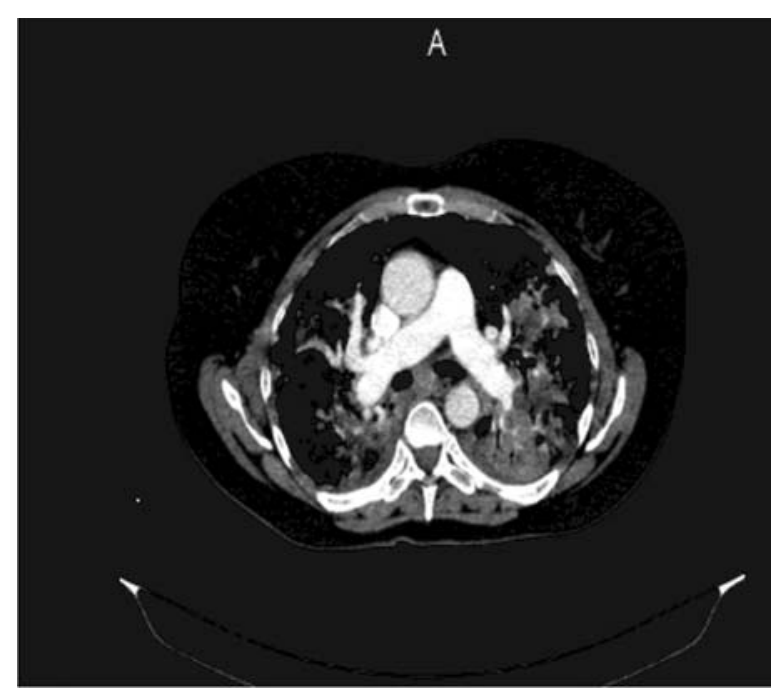

Figure $2-C T$ of patient's lungs arteries

lactates 2.2. Due to the need for monitoring of vital functions, the patient was transferred to the Intensive Unit of the Internal Clinic.

After receiving the patient, an anesthesiologist was consulted, the patient was intubated and connected to mechanical ventilation $\mathrm{A} / \mathrm{C} \mathrm{f12,} \mathrm{FiO} 2$ 0.5. In the further course of the day, the patient was monitored by anesthetist for control of the respiratory pattern. The mode of mechanical ventilation was changed on several occasions depending on the condition of the patient (A/C, BiLevel, spontaneous). A therapy was given by pulmologists (corticosteroids, theophylline preparations, bronchodilatators, oseltamivir, combination of antibiotics for parenteral administration, antimycotics).

Subsequently, the arrival of the medical documentation from Publich Health Institute, a throat swab confirmed the presence of Influenza A, Real Time PCR was positive, as well.

The applied therapy led to a decrease in the value of CRP while maintaining high values of leukocytes. In the longer course of the treatment, a bronchoscopy was repeatedly made, respiratory tract toilete was done, and large amount of dense bleeding content was aspirated. BAL has been taken. Microbiological analysis showed the presence of Acinetobacter spp, which was accompanied bynew increase of inflammatory parameters (CRP, Le). The therapy included the antibiotic Collistin, due to the resistance of the bacterium to the standard antibiogram. Controlled MSCT lung arteries weremade-no signs of thrombotic changes. There were signs of bronchopneumonia on both sides.

Due to the need for further respiratory support, a tracheostomy has been done on the twelfth day of intubation. The day after tracheotomy at the control RTG, a pneumothorax on the leftside was diagnosed. A chest surgeon was consulted and a thoracic drain was placed. Two days after due to repeated pain in the chest and ab- domen, a new RTG of the lung was made which diagnosed the existence of a right-sided pneumothorax and the thoracic drain was placed in the right pleural space. The patient's condition was gradually improving (ABB: $p$ $\mathrm{CO} 2$ 5.5, p O2 7.2, CRP 56.4), and on the seventh day after the placement of the thoracic drains, the patient was extubated. Serial lung radiographs were obtained which showed re-expansion of both lungs. On the 11th day after the placement of the first thoracic drain, the left thoracic drain was removed, and the right one two days later. The patient was then transferred into the pulmonology department for further monitoring where oral antibiotic therapy continued during the next two weeks, as well as other supportive therapy. The patient was discharged in good general condition, hemodynamically stable for further ambulatory monitoring.

\section{DISCUSSION AND CONCLUSION}

People in whom ARDS is recognized often require treatment in intensive care units. There is no specific therapy. The treatment is primarily supportive. Mechanical respiration and adequate use of oxygen play a major role. A key advancement in therapy is the knowledge that lung transduction with positive pressure can exacerbate the existing condition. This attitude has contributed to the development of a new strategy in the treatment of mechanical ventilation using small breathing volumes $(6 \mathrm{ml} / \mathrm{kg})$ in combination with positive pressure at the end of the expiry (PEEP). Appropriate oxygen therapy in other medical conditions can also prevent secondary development of ARDS. Determan and associates performed a controlled randomized study with 150 patients that compared the use of small breathing volumes versus standard patients with critical illness and pointed to reduced production of inflammatory cytokines in patients treated with low air volume (8). Then, there are also adequate nutrition and hydration. Antibiotic therapy is mandatory, most often ex-iuvantibus. Corticosteroids are occasionally administered to resolvethe primary condition, otherwise their use is controversial. Correction of acid base status and other therapies (diuretics, analgetics, anxiolytics, antihypertensives) is regulated as needed. If the recovery does not occur in the first seven days, there is a greater likelihood that progressive lung injury will develop followed by inflammation of the interstitium, and later fibrosis.

Our patient is just an example of this treatment. Complications such as ventialtion-assisted pneumonia and bilateral pneumothorax have prolonged her healing. According to the International Nosocomial Infection Control Consortium (INICC), the frequency of VAP is 13.6 versus 1.000 days spent on ventilation sup- 
port, although the incidence varies depending on the hospital groups and hospital conditions, so that the frequency of VAP ranges between 13-51 and 1000 days spent on ventilation. Patients who survive the ARDS episode usually have lasting effects that are reflected in reduced HRQOL (health related quality of life). Usually we talk about neurocognitive impairment and psychiatric illness. Proper treatment certainly reduces this risk $(9,10)$.

\section{DECLARATION OF INTEREST}

The autors declare that there are no conflicts of interests.

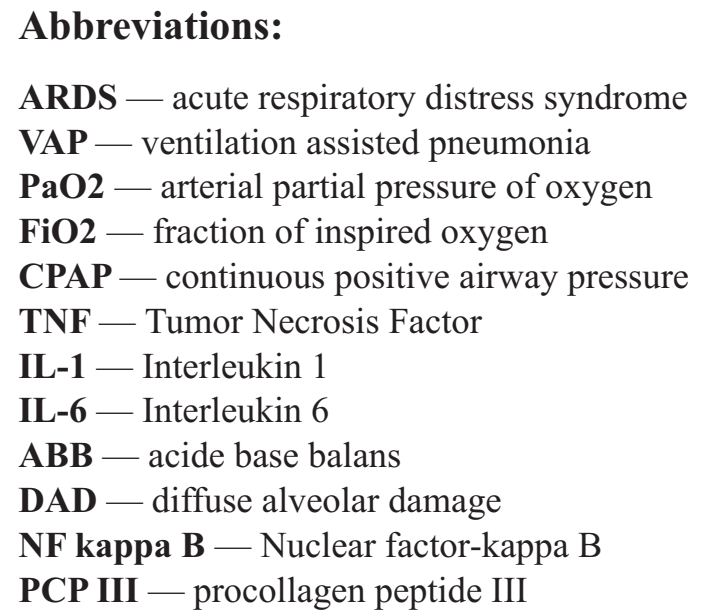

BAL - Bronchoalveolar lavage

MRSA - Methicillin-resistant Staphylococcus aureus

CT - computerized tomography scan

RTG - radioisotope thermoelectric generator

A/C ventialtion - Assist Control ventilation

PCR test - polymerase chain reaction test

WBC — white blood cells

Hgb - hemoglobin

PLT - platelet

CRP $-\mathrm{C}$ reactive protein

AST - aspartate aminotransferase

ALT - alanine aminotransferase

GGT - gamma glutamiletransferase

LDH - lactat dehydrogenase

CK - creatine kinase

$\mathbf{K}$ - kalium ion

$\mathbf{N a}$ - natrium ion

D dimer - fibrin degradation product

PEEP - Positive end-expiratory pressure

INICC - International Nosocomial Infection Control Consortium

HRQOL - health related quality of life

\section{Licensing}

This work is licensed under a Creative Commons Attribution 4.0 International (CC BY 4.0) License

\section{Sažetak}

\section{AKUTNI RESPIRATORNI DISTRES SINDROM KAO KOMPLIKACIJA VIRUSNE PNEUMONIJE - PRIKAZ SLUČAJA \\ Bećir Nevenka, ${ }^{1}$ Milačić Nena, ${ }^{2}$ Kovijanić Zlata, ${ }^{2}$ Bogojević Milan, ${ }^{2}$ Milačić Bojan ${ }^{3}$ \\ ${ }^{1}$ Department of Internal Medicine, General Hospital Kotor, Montenegro \\ ${ }^{2}$ Department of Internal Medicine, Clinical Center of Montenegro, Podgorica Montenegro \\ ${ }^{3}$ Department of Thoracic Surgery, Clinical Center of Montenegro, Podgorica, Montenegro}

ARDS je po život opasno stanje koje zahteva monitoring u jedinicama intenzivne nege. Ne postoji specifični način lečenja. Predstavljamo 49-godišnju pacijentkinju sa ARDS sa komplikacijama, kao što su ventilacijom izazvana pneumonia (VAP) i bilateralni pneumotoraks. Dobro poznavanje procesa može biti od pomoći pri odabiru odgovaraju- ćeg načina lečenja i pri prevenciji, kao i pri prepoznavanju mogućih komplikacija. Adekvatna oksigeno terapija zauzima veoma bitno mesto u lečenju ovih pacijenata.

Ključne reči: ARDS, jedinica intenzivne nege, ventalicijom izazvana pneumonia, bilateralni pneumotoraks, oksigeno terapija. 


\section{REFERENCES}

1. Harman EM. Acute Respiratory Distress Syndrome. Medscape 2017 Oct 03; art 165139. Available from: https:/ /emedicine.medscape.com/article/165139-overview.

2. Ferguson ND, Fan E, Camporota L, Antonelli M, Anzueto A, Beale R, et al. The Berlin definition of ARDS: an expanded rationale, justification, and supplementary material. Intensive care med.2012; 38(10): 1573-82.

3. Rittayamai N, Brochard L. Recent advances in mechanical ventilation in patients with acute respiratory distress syndrome. European Respiratory Review. European Respiratory Society (ERS); 2015; 24(135): 132-40

4. Ćirić Z. Vanbolničke pneumonije. In: Pejčić T. Pneumonije danas. 1st ed. Medicinski fakultet Univerziteta u Nišu, Grafika Galeb-Niš; 2013. p.13-33.

5. Forel JM, Voillet F, Pulina D, Gacouin A, Perrin G, Barrau $\mathrm{K}$, et al. Ventilator-associated pneumonia and ICU mortality in severe ARDS patients ventilated according to a lung-protective strategy. Crit Care. 2012; 16(2): R65.

6. Milačić N, Đurović M, Hasanbegović M, Milačić B, Stevanović D. Severe community aquireded pneumonia caused by Mycoplasma pneumoniae in young female patient. Sanamed. 2015; 10(2):119-22.

7. Pierrakos C, Karanikolas M, Scolletta S, Karamouzos V, Velissaris D. Acute respiratory distress syndrome: pathophysiology and therapeutic options. J Clin Med Res. 2012; 4(1): 7-16.

8 Determann RM, Royakkers A, Wolthuis EK, Vlaar AP, Choi G, Paulus F, et al. Ventilation with lower tidal volumes as compared with conventional tidal volumes for patients without acute lung injury: a preventive randomized controlled trial. Crit Care 2010; 14(1): R1.

9. Herridge VS. Recovery and long-term outcome in acute respiratory distress syndrome. Crit Care Clin. 2011; 27(3): 685-704.

10. Charles MP, Kali A, Easow JM, Joseph NM, Ravishankar M, Srinivasan S et al. Ventilator-associated pneumonia. Australas Med J. 2014; 7(8): 334-44.

\section{Correspondence to / Autor za korespondenciju}

Nevenka Becir, MD

Department of Internal Medicine, General Hospital Kotor

Montenegro

email: nenatv1@gmail.com 